\title{
PENGEMBANGAN INSTRUMEN MICROTEACHING BERDASARKAN PEMBELAJARAN ABAD KE-21
}

\author{
Rahmat Rasmawan \\ Pendidikan Kimia, Universitas Tanjungpura \\ Jalan Prof. Dr. H. Hadari Nawawi, Pontianak, Kalimantan Barat \\ e-mail: rahmat.rasmawan@fkip.untan.ac.id
}

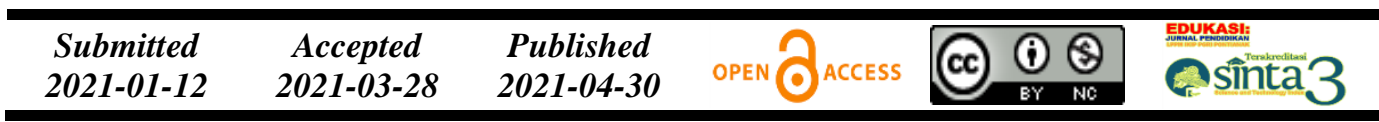

\begin{abstract}
Abstrak
Penelitian bertujuan untuk mengembangkan instrumen Microteaching berkesesuaian dengan keterampilan abad ke-21 yang valid dan reliabel sehingga layak digunakan. Bentuk penelitian yang digunakan adalah Research and Development $(\mathrm{R} \& \mathrm{D})$ dengan mengikuti alur pengembangan ADDIE (Analyze, Design, Develop, Implement, and Evaluate). Subjek penelitian yaitu 30 dosen dan 70 mahasiswa. Validitas instrumen menggunakan Content Validity Index dan Face Validity yang menunjukkan bahwa instrumen dinyatakan valid. Reliabilitas instrumen menggunakan koefisien interkelas korelasi pada merancang dan melaksanakan pembelajaran dan diperoleh nilai koefisien interkelas korelasi dengan kategori sangat reliabel. Berdasarkan hasil penelitian disimpulkan bahwa instrumen yang dikembangkan valid dan layak digunakan untuk mengukur keterampilan peserta Microteaching dalam merancang dan melaksanakan proses pembelajaran abad ke-21.
\end{abstract}

Kata Kunci: pengembangan instrumen; Microteaching; pembelajaran abad ke-21.

\begin{abstract}
The aim of this research was to develop Microteaching assessment instrument that are compatible with the $21^{\text {st }}$-century skill that is valid and reliable so that appropriate to use. The design of this research was Research and Development $(R \& D)$ which refers to ADDIE (Analyze, Design, Develop, Implement, and Evaluate). The research subjects were 30 lecturers and 70 students. The validity of the instrument using the Content Validity Index and Face Validity showed that the instrument was valid. Instrument reliability was using the intraclass correlation coefficient in designing and implementing the learning process obtained result as very reliable. It can be concluded that the developed instrument was valid to be used in assessing participant's Microteaching skills in designing and implementing the $21^{\text {st }}$-century learning process.
\end{abstract}

Keywords: development instrument; Microteaching; $21^{\text {st }}$ century learning.

\section{PENDAHULUAN}

Memasuki abad ke-21, seseorang dituntut untuk mengembangkan sejumlah keterampilan agar berhasil dalam dunia kerja dan kehidupan. Keterampilan yang diperlukan adalah collaboration, critical thinking, communication, dan creativity (Moser, 2017). Keterampilan abad ke-21 dibagi menjadi empat kategori: (1) keterampilan personal, yaitu kreativitas dan problem solving; (2) keterampilan 
sosial, yaitu keterampilan komunikasi dan kolaborasi; (3) pengetahuan dan keterampilan mengelola informasi, termasuk keterampilan berpikir secara kritis dan analitis; serta (4) keterampilan digital literasi (Chalkiadaki, 2018).

Persiapan seseorang dalam menguasai keterampilan abad ke-21 dapat dikembangkan melalui pendidikan. Penyelenggaraan pendidikan hendaknya tidak hanya sebatas mengajarkan pengetahuan, tetapi perlu dibuat standar yang mengintegrasikan keterampilan abad ke-21 dalam proses pendidikan (Alismail \& McGuire, 2015). Usaha yang dapat dilakukan antara lain memberikan kesempatan siswa berkolaborasi dan berkomunikasi melalui diskusi, pemberian masalah dalam kehidupan sehari-hari, serta menciptakan sesuatu untuk mengatasi masalah yang dihadapi dengan tujuan melatih keterampilan penyelesaian masalah, berpikir kritis, kreatif, inovatif, dan memanfaatkan literasi digital untuk menyelesaikan permasalahan yang diberikan (Yunus et al., 2017). Penilaian yang dilakukan dalam proses pembelajaran bukan hanya sebatas penguasaan sejumlah materi, tetapi juga menilai keterampilan, seperti menganalisis, berpikir ktitis, penyelesaian masalah, kreativitas, dan sikap dalam berdiskusi, bekerja sama, menghargai teman, kepedulian, serta menunjukkan karakter terpuji (Subagia \& Wiratma, 2016).

Pemanfataan Microteaching di Indonesia belum sepenuhnya dioptimalkan dalam rangka latihan mengajar berdasarkan keterampilan abad ke-21. Kegiatan Microteaching hanya digunakan untuk melatih keterampilan dasar mengajar, seperti keterampilan membuka, menutup, mengelola pembelajaran, memberikan penguatan, menjelaskan materi, bertanya dasar, dan bertanya lanjut tanpa mengaitkan dengan keterampilan dasar melaksanakan pembelajaran yang dapat meningkatkan keterampilan abad ke-21 (Setiawan \& Mulyati, 2019; Khuriyah, 2017; Tazali, 2017). Beberapa penelitian telah mengembangkan bahan ajar untuk mempermudah kegiatan Microteaching yang berisikan penguasaan keterampilan pedagogi dalam mengelola pembelajaran, tetapi belum membahas secara rinci tentang proses pembelajaran yang dapat meningkatkan keterampilan abad ke-21 (Murtafiah \& Lukitasari, 2019; Rahayu \& Mertha, 2017). 
Edukasi: Jurnal Pendidikan, Volume 19 Nomor 1 Tahun 2021

Pengembangan Instrumen Microteaching.......

Rahmat Rasmawan

Halaman 31-45

Pelaksanaan Microteaching di Program Studi Pendidikan Kimia Fakultas Keguruan dan Ilmu Pendidikan (FKIP) Universitas Tanjungpura juga belum mengoptimalkan latihan dalam mengajar berdasarkan keterampilan abad ke-21. Penilaian merancang pembelajaran dalam latihan Microteaching hanya difokuskan kepada kelengkapan dalam menyusun rencana pembelajaran, yaitu rencana pelaksanaan pembelajaran, lembar kerja siswa, media, dan evaluasi tanpa melihat apakah rancangan yang dibuat dapat meningkatkan keterampilan abad ke21. Penilaian dalam melaksanakan pembelajaran dari latihan Microteaching hanya difokuskan kepada keterampilan mahasiswa dalam menjelaskan materi, menggunakan media, dan melakukan evaluasi pembelajaran tanpa melihat apakah proses pembelajaran dapat memunculkan keterampilan abad ke-21, seperti memberikan kesempatan kepada mahasiswa untuk berpikir secara kritis dalam proses pembelajaran, mengembangkan keterampilan problem solving dari permasalahan yang diberikan dosen ketika pembelajaran, dan menciptakan suasana yang memungkinkan terjadinya komunikasi sesama mahasiswa.

Kegiatan Microteaching perlu memperhatikan keterampilan abad ke-21 serta kompetensi lulusan calon guru agar memenuhi standar yang ditetapkan oleh pemerintah dan dunia kerja. Dengan demikian, perlu dikembangkan instrumen Microteaching yang sesuai dengan pembelajaran abad ke-21, yaitu keterampilan dalam merancang dan melaksanakan pembelajaran yang mampu meningkatkan keterampilan berpikir kritis, penyelesaian masalah, kolaborasi, komunikasi, literasi, dan kecakapan hidup mahasiswa. Penggunaan instrumen Microteaching berbasis pembelajaran abad ke-21 memberikan gambaran tentang keterampilan mahasiswa calon guru dalam merancang dan melaksanakan proses pembelajaran yang dapat membantu siswa meningkatkan keterampilan yang dibutuhkan pada abad ke-21, serta dijadikan bahan refleksi untuk memperbaiki kualitas kegiatan pembelajaran Microteaching. Berdasarkan permasalahan yang telah diuraikan, maka penelitian bertujuan untuk mengembangkan instrumen Microteaching yang berkesesuaian dengan keterampilan abad ke-21 yang valid dan reliabel sehingga layak untuk digunakan. 


\section{METODE}

Bentuk penelitian yang digunakan adalah Research and Development (R\&D) dengan mengacu pada model pengembangan ADDIE yang merupakan singkatan dari analyze, design, develop, implement, and evaluate (Branch, 2009). Tahap analyze dilakukan studi pendahuluan, yaitu melakukan observasi dan wawancara terkait potensi, serta hambatan atau kendala yang dihadapi pada pelaksanaan Microteaching di Program Studi Pendidikan Kimia FKIP Universitas Tanjungpura. Pemilihan responden wawancara dilakukan secara acak dengan mengambil tiga dosen pembimbing Microteaching dan lima mahasiswa yang telah mengikuti kegiatan Microteaching pada Program Studi Pendidikan Kimia. Data yang diperoleh dari observasi dan wawancara selanjutnya dianalisis untuk menentukan potensi dan masalah dalam pengelolaan pelaksanaan Microteaching di Program Studi Pedidikan Kimia FKIP Universitas Tanjungpura.

Tahap selanjutnya adalah design, yaitu mendesain instrumen penilaian Microteaching berdasarkan proses pembelajaran abad ke-21 dengan membuat kisikisi instrument yang mencakup capaian pembelajaran, indikator keberhasilan, dan aspek yang diamati. Capaian pembelajaran dalam penelitian adalah keterampilan mahasiswa dalam merancang dan melaksanakan pembelajaran abad ke-21 melalui praktik Microteaching. Indikator keberhasilan dalam merancang pembelajaran adalah format rancangan pembelajaran, merumuskanan indikator pencapaian kompetensi, tujuan pembelajaran, materi ajar, metode pembelajaran, pemilihan media dan sumber belajar, serta merancang langkah-langkah pembelajaran dan penilaian. Indikator keberhasilan dalam melaksanakan praktik pembelajaran adalah keterampilan membuka, menjelaskan, menggunakan media, bertanya, mengelola pembelajaran, memberi penguatan, melakukan penilaian, dan menutup pembelajaran (Dewi, 2018; Mishra \& Mehta, 2017; Adi, 2015). Aspek yang diamati dalam penelitian adalah kriteria yang dijadikan pegangan dalam menilai indikator keberhasilan.

Hasil yang diperoleh pada tahap design dijadikan dasar untuk melanjutkan ke tahap develop, yaitu mengembangkan draf instrumen yang kemudian dilakukan validasi dengan melibatkan sepuluh pakar untuk content validity dan calon 
pengguna untuk face validity. Pakar dipilih sebanyak sepuluh dosen dengan jabatan akademik minimal lektor kepala. Pengguna instrumen (subjek penelitian) terdiri 30 dosen pembimbing Microteaching dengan bidang keahlian termasuk dalam rumpun IPA atau Pendidikan IPA (Kimia, Fisika, dan Biologi) dan 70 mahasiswa Program Studi Pendidikan Kimia yang mendaftar dalam kegiatan Microteaching.

Setelah draf instrumen Microteaching dinyatakan valid oleh pakar dan responden memberikan tanggapan positif, maka dilanjutkan ke tahap implement, yaitu memberikan draf instrumen kepada penilai. Penilai instrumen berjumlah sepuluh dosen pembimbing kegiatan Microteaching dari Program Studi Pendidikan Kimia yang bertugas untuk menilai satu mahasiswa yang sama dalam merancang dan melaksanakan praktik Microteaching dengan tujuan menentukan reliabilitas antarpenilai dari draf instrumen yang telah dikembangkan. Tahap akhir dari penelitian adalah evaluate, yaitu melakukan evaluasi dan perbaikan draf instrumen Microteaching dari hasil yang diperoleh pada tahap implement.

Alat pengumpul data yang digunakan pada tahap analyze adalah lembar observasi dan pedoman wawancara. Observasi digunakan untuk melihat pelaksanaan kegiatan Microteaching yang dilakukan dengan aspek yang diamati, yaitu: (1) pelaksanaan praktik mengajar; (2) evaluasi diri; dan (3) umpan balik dari dosen pembimbing Microteaching. Wawancara digunakan untuk mengetahui hambatan atau kendala yang dihadapi oleh dosen pembimbing dan mahasiswa selama melaksanakan praktik Microteaching dengan aspek yang ditanyakan, yaitu: (1) kelemahan dan kelebihan instrumen; (2) pengembangan keterampilan mengelola pembelajaran berdasarkan keterampilan abad ke-21; serta (3) saran dan masukan untuk memperbaiki kualitas dari praktik Microteaching.

Alat pengumpul data pada tahap develop adalah lembar penilaian content validity yang diberikan kepada pakar dan lembar penilaian face validity yang diberikan kepada mahasiswa. Aspek yang diukur pada lembar penilaian content validity, yaitu: (1) kesesuaian indikator keberhasilan dengan aspek yang diamati serta menggambarkan keterampilan dalam merancang dan melaksanakan pembelajaran berdasarkan keterampilan abad ke-21; dan (2) aspek yang diamati mengakomodasi pembelajaran keterampilan abad ke-21, dirumuskan dengan jelas, 
dapat diamati oleh penilai atau pengamat serta tidak memunculkan makna ganda atau ambigu. Adapun kriteria penilaian adalah item dikatakan relevan jika validator memberikan penilaian dengan skor 3 (relevan) atau 4 (sangat relevan) dan tidak relevan jika diperoleh skor 2 (kurang relevan) atau 1 (tidak relevan). Aspek yang diukur pada lembar penilaian face validity adalah tanggapan mahasiswa terhadap instrumen Microteaching dengan memberikan jawaban "ya" atau "tidak" dari aspek ketertarikan, kejelasan, kebermaknaan, dan kegunaan dalam mengukur keterampilan merancang dan melaksanakan pembelajaran berdasarkan pada keterampilan abad ke-21.

Data yang terkumpul dari hasil observasi dan wawancara pada tahap analyze dianalisis secara kualitatif-deskriptif. Data yang terkumpul dari penilaian content validity dianalisis secara kuantitatif dengan menentukan nilai CVI (Content Validity Index) dan dianggap valid jika memperoleh nilai CVI minimal 0,80 (Yusoff, 2019). Penentuan nilai CVI menggunakan rumus (1).

$$
\mathrm{CVI}=\frac{\text { Jumlah validator yang menyatakan relevan }}{\text { Jumlah seluruh validator }}
$$

Data yang terkumpul dari penilaian face validity selanjutnya ditentukan persentase persetujuan dari responden yang terlibat. Data yang terkumpul dari tahap implement selanjutnya dianalisis untuk menentukan apakah terdapat kesepakatan antarpenilai dalam menilai kegiatan Microteaching dengan menggunakan instrumen yang digunakan, kemudian menghitung nilai koefisien interclass correlation menggunakan program aplikasi SPSS. Untuk melihat ada atau tidaknya perbedaan kesepakatan secara signifikan dianalisis dengan anova oneway dengan taraf signifikansi 5\% menggunakan program aplikasi SPSS. Jika nilai sig yang diperoleh lebih besar dari (>) 0,05, maka tidak terdapat perbedaan penilaian yang dilakukan oleh pengamat (penilai).

\section{HASIL DAN PEMBAHASAN}

Tahap pertama mengembangkan instrumen Microteaching adalah analyze, yaitu studi pendahuluan tentang potensi, hambatan, dan kendala dalam pelaksanaan Microteaching di Program Studi Pendidikan Kimia FKIP Universitas Tanjungpura. 
Edukasi: Jurnal Pendidikan, Volume 19 Nomor 1 Tahun 2021

Pengembangan Instrumen Microteaching.......

Rahmat Rasmawan

Halaman 31-45

Hasil wawancara dengan dosen pembimbing Microteaching diketahui bahwa keterampilan merancang hanya difokuskan pada kesesuaian format rancangan pembelajaran yang berlaku. Keterampilan melaksanakan pembelajaran hanya difokuskan pada keterampilan dasar mengajar, sehingga kurang memperhatikan pembelajaran yang dapat meningkatkan keterampilan abad ke-21. Hasil wawancara dengan mahasiswa menunjukkan bahwa mahasiswa cenderung mengembangkan keterampilan yang dituntut dari instrumen penilaian yang diberikan. Instrumen penilaian berdasarkan pembelajaran abad ke-21 perlu dikembangkan sebagai panduan dosen pembimbing dalam menilai dan panduan mahasiswa untuk mengembangkan keterampilan mengajar berdasarkan keterampilan abad ke-21.

Hasil pada tahap analyze dijadikan dasar untuk melanjutkan ke tahap design. Tahap design diawali dengan menyusun planning pengembangan instrumen penilaian keterampilan Microteaching berasarkan pembelajaran abad ke-21 dengan menyusun kisi-kisi berdasarkan kegiatan menelaah capaian pembelajaran, merumuskan indikator sesuai capaian pembelajaran, dan aspek yang diamati. Adapun kisi-kisi instrumen penilaian keterampilan merancang pembelajaran dapat dilihat pada Tabel 1.

Berdasarkan Tabel 1 diketahui bahwa keterampilan merancang pembelajaran pada praktik Microteaching yang dinilai yaitu: kelengkapan format rancangan pembelajaran; keterampilan dalam merumuskan indikator pencapaian kompetensi; merumuskan tujuan pembelajaran; materi ajar; metode; pemilihan media dan sumber belajar; serta merancang langkah-langkah pembelajaran dan penilaian. Perencanaan pembelajaran berperan penting sebagai pegangan guru tentang apa yang akan dicapai siswa, bagaimana cara mencapai hal tersebut, dan memastikan bahwa siswa mencapai apa yang diharapkan serta membantu mengontrol guru dalam pelaksanaan pembelajaran (Papa-Gusho \& Biçaku-Çekrezi, 2015). Berkaitan dengan keterampilan abad ke-21, seorang guru harus dapat merancang pembelajaran yang dapat mengembangkan keterampilan berpikir secara kritis, penyelesaian masalah, kreatif, inovatif, serta dapat mengembangkan karakter siswa dan penilaian dilakukan secara menyeluruh, bukan hanya pada aspek kognitif saja (Faulkner \& Latham, 2016). 
Tabel 1 Kisi-Kisi Instrumen Microteaching Keterampilan Merancang Pembelajaran Abad ke-21

\begin{tabular}{l} 
Indikator Keberhasilan \\
\hline Format Rancangan \\
Pembelajaran \\
\\
Perumusan Indikator \\
Pencapaian Kompetensi
\end{tabular}

Aspek yang Diamati

Mencantumkan identitas sekolah, mata pelajaran, kelas dan semester, materi pokok, alokasi waktu, Kompetensi Inti (KI) dan Kompetensi Dasar (KD), indikator pencapaian kompetensi, tujuan pembelajaran, materi pelajaran, pendekatan/metode/model, media/alat peraga, sumber belajar, langkah pembelajaran, penilaian dan lampiran.

Pencapaian Kompetensi Dirumuskan sebagai kemampuan minimal yang diamati sebagai pemenuhan KD serta dirumuskan dengan kata kerja operasional yang dapat diukur atau dilakukan penilaian sesuai dengan karakteristik mata pelajaran.

Perumusan Tujuan

Pembelajaran

Dirumuskan dalam bentuk deskripsi, memuat gambaran proses pembelajaran, KD yang hendak dicapai menggunakan kata kerja operasional yang dapat diamati dan diukur yang mencakup sikap, pengetahuan, dan keterampilan.

Merumuskan Materi Ajar Materi yang disajikan memuat fakta, konsep, prinsip, atau prosedur yang relevan serta sesuai dengan alokasi waktu yang ditetapkan dan sesuai dengan karakteristik siswa.

Merumuskan Model dan Model dan metode pembelajaran berkesesuaian dengan tujuan Metode Pembelajaran pembelajaran serta dapat membuat siswa terlibat aktif dalam pembelajaran dan berbasis aktivitas pengembangan keterampilan abad ke-21.

Pemilihan Media dan Sumber Belajar

Digunakan dalam skenario pembelajaran, mendukung pencapaian kompetensi serta sesuai dengan karakteristik siswa dan mudah digunakan.

Merancang LangkahLangkah Pembelajaran Didesain agar memungkinkan siswa mengikuti proses pembelajaran secara interaktif, inspiratif, menyenangkan, menantang, dan dapat memotivasi siswa mengikuti proses pembelajaran.

Mengintegrasikan keterampilan abad ke-21 dalam skenario pembelajaran, meliputi karakter utama (religius, nasionalis, kemandirian, gotong royong, dan integritas), keterampilan berpikir kritis dan penyelesaian masalah (critical thinking dan problem solving), kreativitas dan inovasi (creativity and innovation), kolaborasi (collaboration), serta keterampilan literasi (termasuk literasi informasi, media, dan teknologi informasi).

Sesuai dengan langkah-langkah model pembelajaran yang dipakai serta kesesuaian dengan alokasi waktu yang ditentukan.

Merancang Penilaian Penilaian yang dirancang berkesesuaian dengan indikator pencapaian kompetensi dan memuat lingkup penilaian yang lengkap (sikap, pengetahuan, dan keterampilan) serta berkesesuaian dengan bentuk instrumen yang akan digunakan.

Berdasarkan pada instrumen penilaian rancangan pembelajaran yang dikembangkan, capaian yang akan diperoleh mahasiswa dalam mengikuti pembelajaran dan cara mencapai hal tersebut digambarkan dalam keterampilan mahasiswa merumuskan indikator pencapaian kompetensi, perumusan tujuan pembelajaran, rancangan media atau sumber belajar yang digunakan, serta menentukan pendekatan, metode, atau model yang sesuai. Dalam instrumen yang 
Edukasi: Jurnal Pendidikan, Volume 19 Nomor 1 Tahun 2021

Pengembangan Instrumen Microteaching.......

Rahmat Rasmawan

Halaman 31-45

dikembangkan, keterampilan merancang pembelajaran difokuskan bagaimana keterampilan abad ke-21 diintegrasikan dalam skenario pembelajaran. Rancangan penilaian tidak hanya berfokus pada kemampuan kognitif saja, tetapi juga aspek keterampilan dan sikap sesuai dengan apa yang ingin dicapai.

Pengembangan kisi-kisi instrumen penilaian keterampilan melaksanakan pembelajaran difokuskan pada pengetahuan dasar, metakognitif, dan humanisme berdasarkan keterampilan abad ke-21. Sebagai contoh, indikator keterampilan membuka pelajaran, penilaian diarahkan pada penyampaian manfaat dan tujuan yang hendak dicapai terkait dengan materi yang akan dipelajari (pengetahuan dasar) serta memancing pengetahuan awal siswa dengan pertanyaan yang dapat meningkatkan kemampuan berpikir kritis, problem solving, dan literasi (pengetahuan metakognitif). Adapun kisi-kisi instrumen penilaian Microteaching dalam melaksanakan pembelajaran abad ke-21 dapat dilihat pada Tabel 2.

Draf instrumen penilaian microteacing selanjutnya dilakukan validasi. Terdaoat dua jenis validasi yang dilakukan, yaitu content validity dan face validity. Content validity melibatkan sepuluh orang pakar bidang pembelajaran dengan jabatan fungsional lektor kepala yang diminta untuk menentukan relevan atau tidaknya setiap aspek yang diukur. Hasil content validity draf instrumen penilaian Microteaching dapat dilihat pada Tabel 3.

Berdasarkan Tabel 3 diketahui bahwa draf instrumen penilaian Microteaching dalam merancang dan melaksanakan pembelajaran berdasarkan abad ke-21 dinyatakan valid. Hasil tersebut menunjukkan bahwa aspek-aspek yang diamati sesuai dengan indikator yang hendak dicapai, dapat diamati, berkesesuaian dengan pembelajaran abad ke-21, dirumuskan dengan jelas, dan tidak memunculkan makna ganda. Makna valid memiliki pengertian bahwa instrumen yang dikembangkan telah tepat dan dapat mengukur apa yang ingin diobservasi atau diamati sehingga dapat digunakan (Yane \& Rustanto, 2020; Nurhayati et al., 2019; Arahim, 2018; Mora et al., 2016). Dengan demikian, instrumen penilaian Microteaching yang dikembangkan dapat mengukur dan digunakan untuk menilai keterampilan siswa dalam merancang dan melaksanakan proses pembelajaran berdasarkan abad ke-21. 


\section{Tabel 2 Kisi-Kisi Instrumen Microteaching Keterampilan Melaksanakan} Pembelajaran Abad ke-21

\begin{tabular}{|c|c|}
\hline $\begin{array}{c}\text { Indikator } \\
\text { Keberhasilan }\end{array}$ & Aspek yang Diamati \\
\hline $\begin{array}{l}\text { Keterampilan } \\
\text { Membuka Pelajaran }\end{array}$ & $\begin{array}{l}\text { Penyampaian manfaat dalam mempelajari yang akan dipelajari. } \\
\text { Mengajukan pertanyaan awal yang dapat memancing siswa } \\
\text { mengungkapkan pengetahuan awal yang dimiliki (melatih berpikir } \\
\text { secara kritis, problem solving, dan literasi). } \\
\text { Menyampaikan tujuan pembelajaran dengan jelas dan dapat dipahami } \\
\text { oleh siswa. } \\
\text { Menyampaikan garis besar materi yang akan dipelajari. }\end{array}$ \\
\hline $\begin{array}{l}\text { Keterampilan } \\
\text { Menjelaskan Materi }\end{array}$ & $\begin{array}{l}\text { Penyampaian yang sistematis (dari mudah ke sulit, dari konkret ke } \\
\text { abstrak, dari yang dekat dengan lingkungan sampai ke yang jauh). } \\
\text { Menjelaskan disertai contoh yang riil/mengaitkan informasi terkini. } \\
\text { Kalimat yang digunakan dalam menjelaskan mudah dipahami, jelas, } \\
\text { intonasi/nada bicara sesuai kebutuhan dan bahasa digunakan santun. }\end{array}$ \\
\hline $\begin{array}{l}\text { Keterampilan } \\
\text { Menggunakan Media } \\
\text { dan Sumber Belajar }\end{array}$ & $\begin{array}{l}\text { Media dan sumber belajar digunakan secara efektif dan efisien } \\
\text { (dilakukan secara tepat dan aman, serta terampil menggunakan } \\
\text { media/alat/bahan). } \\
\text { Mengajak siswa untuk berpartisipasi dengan menggunakan media dan } \\
\text { sumber belajar. } \\
\text { Menarik perhatian siswa. }\end{array}$ \\
\hline Keterampilan Bertanya & $\begin{array}{l}\text { Menyampaikan pertanyaan dengan jelas, dimulai dari yang mudah ke } \\
\text { arah yang lebih sulit. } \\
\text { Memberikan kesempatan kepada siswa untuk berpikir dalam menjawab } \\
\text { pertanyaan yang diberikan. } \\
\text { Pertanyaan yang diberikan dapat memunculkan keterampilan berpikir } \\
\text { kritis, problem solving, dan melatih literasi siswa. } \\
\text { Pertanyaan yang diberikan dapat meningkatkan keterlibatan siswa } \\
\text { dalam menjawab pertanyaan tersebut. }\end{array}$ \\
\hline $\begin{array}{l}\text { Keterampilan } \\
\text { Mengelola } \\
\text { Pembelajaran }\end{array}$ & $\begin{array}{l}\text { Melaksanakan langkah-langkah pembelajaran aktif learning } \\
\text { (mendorong untuk melakukan kegiatan mengalami langsung). } \\
\text { Proses pembelajaran dapat menumbuhkan keterampilan berpikir kritis, } \\
\text { kreatif, kolaboratif, problem solving, dan literasi. } \\
\text { Membiasakan pembentukan karakter siswa, seperti jujur, disiplin, } \\
\text { tanggung jawab, percaya diri, toleransi, dan mandiri. } \\
\text { Membimbing siswa secara klasikal, kelompok, atau individual. }\end{array}$ \\
\hline $\begin{array}{l}\text { Keterampilan } \\
\text { Memberikan } \\
\text { Penguatan }\end{array}$ & $\begin{array}{l}\text { Membimbing siswa dalam keterbukaan (membenarkan dan/atau } \\
\text { mengakui kekurangan dalam proses pembelajaran) dengan bahasa yang } \\
\text { sopan, santun, dan tidak mendiskriminasi siswa. } \\
\text { Memberikan penghargaan kepada siswa yang dapat memotivasi dalam } \\
\text { pembelajaran. }\end{array}$ \\
\hline $\begin{array}{l}\text { Keterampilan } \\
\text { Melakukan Penilaian }\end{array}$ & $\begin{array}{l}\text { Memantau kemajuan belajar siswa dengan memberikan pertanyaan } \\
\text { untuk memantau capaian siswa. } \\
\text { Melaksanakan penilaian hasil belajar sesuai dengan perencanaan. } \\
\text { Menindaklanjuti hasil penilaian selama pembelajaran berlangsung. }\end{array}$ \\
\hline $\begin{array}{l}\text { Keterampilan Menutup } \\
\text { Pelajaran }\end{array}$ & $\begin{array}{l}\text { Melibatkan siswa dalam membuat rangkuman dan umpan balik. } \\
\text { Melakukan refleksi dan tindak lanjut yang meliputi keterampilan dalam } \\
\text { membimbing siswa melakukan evaluasi diri menemukan manfaat. } \\
\text { Memberikan umpan balik terhadap proses pembelajaran. }\end{array}$ \\
\hline
\end{tabular}


Tabel 3 Hasil Penilian Pakar pada Content Validity

\begin{tabular}{|c|c|c|c|c|}
\hline \multirow[b]{2}{*}{ Aspek } & \multicolumn{2}{|c|}{ Penilaian Pakar } & \multirow[b]{2}{*}{ VCI } & \multirow[b]{2}{*}{ Kategori } \\
\hline & Relevan & $\begin{array}{c}\text { Tidak } \\
\text { Relevan }\end{array}$ & & \\
\hline Kesesuaian indikator dengan aspek yang diamati. & 9 & 1 & 0,9 & Valid \\
\hline Indikator keberhasilan menggambarkan & 9 & 1 & 0,9 & Valid \\
\hline keterampilan dalam merancang pembelajaran. & & & & \\
\hline $\begin{array}{l}\text { Indikator keberhasilan menggambarkan } \\
\text { keterampilan dalam melaksanakan pembelajaran. }\end{array}$ & 8 & 2 & 0,8 & Valid \\
\hline $\begin{array}{l}\text { Aspek yang diamati mengakomodasi pembelajaran } \\
\text { keterampilan abad ke- } 21 \text {. }\end{array}$ & 9 & 1 & 0,9 & Valid \\
\hline Aspek yang diamati dirumuskan dengan jelas. & 10 & 0 & 1,0 & Valid \\
\hline Aspek yang diamati dapat dilihat dari pengamatan. & 9 & 1 & 0,9 & Valid \\
\hline $\begin{array}{l}\text { Aspek yang diamati tidak memunculkan makna } \\
\text { ganda/ambigu. }\end{array}$ & 9 & 1 & 0,9 & Valid \\
\hline
\end{tabular}

Face validity dilakukan terhadap subjek penelitian yang terdiri dari 30 dosen pembimbing dan 70 mahasiswa yang sedang mengikuti praktik pengalaman lapangan untuk menilai draf instrumen. Face validity diperlukan untuk mengukur sejauh mana alat, produk, dan desain yang dibuat dapat diterima secara sosial oleh calon pengguna (Gregory, 2013). Suatu instrumen dibutuhkan persetujuan penggunaan dan terlihat relevan dari sudut pandang calon pengguna walaupun tidak memiliki keahlian khusus yang dibutuhkan untuk memberikan penilaian seperti pada validitas konten (Taherdoost, 2016). Nilai yang diperoleh dari hasil analisis draf instrumen Microteaching oleh responden untuk aspek ketertarikan sebesesar 91\%, kejelasan sebesar 90\%, kebermaknaan sebesar 90\%, dan kegunaan sebesar 92\%. Berdasarkan hasil tersebut, diketahui bahwa responden memberikan respons menerima instrumen Microteaching yang dikembangkan.

Tahap selanjutnya yang dilakukan adalah implement, yaitu menerapkan draf instrumen Microteaching. Sepuluh dosen pembimbing kegiatan Microteaching dari Program Studi Pendidikan Kimia menilai satu mahasiswa yang sama dalam merancang dan melaksanakan praktik Microteaching. Data hasil pengamatan selanjutnya ditentukan nilai koefisien interkelas korelasi (Intraclass Correlation Coefisien/ICC). Hasil analisis dapat dilihat pada Tabel 4. 
Tabel 4 Hasil Perhitungan Interclass Correlation Coefisien

\begin{tabular}{|c|c|c|c|c|c|c|}
\hline \multirow[t]{2}{*}{ Capaian Pembelajaran } & \multicolumn{2}{|c|}{ Reliability Statistic } & \multicolumn{2}{|c|}{ ANOVA } & \multicolumn{2}{|c|}{$\begin{array}{c}\text { Interclass } \\
\text { Correlation } \\
\text { Coefisien } \\
\end{array}$} \\
\hline & $\begin{array}{c}\text { Cronbach's } \\
\text { Alpa }\end{array}$ & $\begin{array}{l}\text { Nof } \\
\text { Item }\end{array}$ & $\mathbf{F}$ & Sig & $\begin{array}{c}\text { Single } \\
\text { Measure }\end{array}$ & $\begin{array}{l}\text { Average } \\
\text { Measure }\end{array}$ \\
\hline $\begin{array}{l}\text { Merancang kegiatan Microteaching } \\
\text { berdasarkan pembelajaran abad } 21 .\end{array}$ & 0,960 & 10 & 1,371 & 0,215 & 0,705 & 0,960 \\
\hline $\begin{array}{l}\text { Melaksanakan kegiatan } \\
\text { Microteaching berdasarkan } \\
\text { pembelajaran abad } 21 .\end{array}$ & 0,907 & 26 & 1,282 & 0,259 & 0,494 & 0,907 \\
\hline
\end{tabular}

Keterangan: $\mathrm{N}$ adalah jumlah aspek yang diamati observer; Sig adalah taraf signifikansi uji $\mathrm{F}$; Average Measure adalah nilai rata-rata koefisien interclass correlation.

Berdasarkan Tabel 4 diketahui bahwa nilai signifikansi pada analisis ANOVA menunjukkan lebih besar dari (>) 0,05 pada tiap capaian pembelajaran, sehingga disimpulkan tidak terdapat perbedaan penilaian dari 10 dosen pembimbing yang menilai rancangan dan pelaksanaan pembelajaran dalam praktik Microteaching menggunakan instrumen penilaian yang dikembangkan. Nilai interclass correlation coefisien pada merancang sebesar 0,960 dan melaksanakan kegiatan merancang pembelajaran sebesar 0,907, sehingga hasil tersebut masuk dalam kategori sangat reliabel. Hasil yang diperoleh menunjukkan bahwa penilai Microteaching pada tahap implementasi memiliki persepsi yang sama dalam melakukan penilaian dengan menggunakan instrumen yang dikembangkan. Instrumen dalam mengukur objek atau subjek yang diamati harus dapat membuat beberapa penilai memiliki persepsi yang sama tentang apa yang akan diamatinya dan jika penilai memiliki persepsi yang berbeda, maka instrumen observasi tersebut tidak layak digunakan dan harus direvisi (Shekhar et al., 2015). Dengan demikian, instrumen penilaian yang dikembangkan valid dan layak digunakan untuk mengukur keterampilan mahasiswa dalam merancang dan melaksanakan pembelajaran abad ke-21 pada praktik Microteaching.

\section{SIMPULAN}

Berdasarkan hasil penelitian, instrumen Microteaching yang dikembangkan dinyatakan valid jika ditinjau dari Content Validity Index dan Face Validity. Hasil perhitungan reliabilitas instrumen yang menggunakan interclass correlation 
Edukasi: Jurnal Pendidikan, Volume 19 Nomor 1 Tahun 2021

Pengembangan Instrumen Microteaching.......

Rahmat Rasmawan

Halaman 31-45

coefisien pada merancang dan melaksanakan kegiatan berada pada kategori sangat reliabel. Dengan demikian, disimpulkan bahwa instrumen yang dikembangkan valid dan layak digunakan untuk mengukur keterampilan peserta Microteaching dalam merancang dan melaksanakan proses pembelajaran abad ke-21. Saran yang diberikan berdasarkan hasil penelitian adalah dalam pemilihan penilai Microteaching yang akan menilai praktikan. Penelitian yang dilakukan hanya menggunakan penilai dari Program Studi Pendidikan Kimia saja, tidak melibatkan penilai dari program studi yang lain. Penilai dari program studi yang lain perlu dilibatkan agar instrumen Microteaching dapat digunakan untuk berbagai macam bidang pelajaran, seperti bidang IPA, sosial, maupun bahasa.

\section{DAFTAR PUSTAKA}

Adi, I. P. P. (2015). Sistem evaluasi dan kesiapan pelaksanaan PPL-real di sekolah mitra. JPI (Jurnal Pendidikan Indonesia), 4(2), 657-665. https://doi.org/ 10.23887/ jpi-undiksha.v4i2.6062.

Alismail, H. A., \& McGuire, P. (2015). 21st century standards and curriculum: Current research and practice. Journal of Education and Practice, 6(6), 150154.

Arahim, I. A. (2018). Pengembangan lembar kerja siswa dengan visualisasi berbantu Macromedia Flash pada pembelajaran Matematika. Edukasi: Jurnal Pendidikan, 16(1), 116-123. http://dx.doi.org/10.31571/ edukasi.v16i1.842.

Branch, R. M. (2009). Instructional design: The ADDIE approach. New York: Springer Science \& Business Media.

Chalkiadaki, A. (2018). A systematic literature review of 21st century skills and competencies in primary education. International Journal of Instruction, 11(3), 1-16. https://doi.org/10.12973/iji.2018.1131a.

Dewi, K. T. (2018). Developing assessment instrument based curriculum 2013 for teaching Micro Teaching in English Education Department of Undiksha. International Journal of Social Sciences and Humanities, 2(3), 95-106. https://doi.org/10.29332/ijssh.v2n3.205. 
Faulkner, J., \& Latham, G. (2016). Adventurous lives: Teacher qualities for $21 \mathrm{st}$ century learners. Australian Journal of Teacher Education, 41(4), 137-150. https://doi.org/10.14221/ajte.2016v41n4.9.

Gregory, R. J. (2013). Psychological testing: History, principles and applications (7th edition). Wheaton College: Pearson.

Khuriyah. (2017). Analisis pelaksanaan Microteaching mahasiswa Program Studi Pendidikan Agama Islam. At-Tarbawi: Jurnal Kajian Kependidikan Islam. 2(2), 175-194. https://doi.org/10.22515/attarbawi.v2i2.990.

Mishra, P., \& Mehta, R. (2017). What we educators get wrong about 21st-century learning: Results of a survey. Journal of Digital Learning in Teacher Education, 33(1), 6-19. https://doi.org/10.1080/21532974.2016.1242392.

Mora, J. N. C., Silva, F. B., Lopez, R. R., \& Cortez, R. E. C. (2016). Design, adaptation and content validity process of a questionnaire: A case study. International Journal of Management (IJM), 7(7), 204-216.

Moser, D. (2017). Driving 21st century learning. R\&E-SOURCE (Open Online Journal for Research and Education), Special Issue, 115-125.

Murtafiah, W., \& Lukitasari, M. (2019). Developing pedagogical content knowledge of mathematics pre-service teacher through Microteaching lesson study. Jurnal Pendidikan Matematika, 13(2), 201-218. https://doi.org/10.22342/jpm.13.2.7663.201-218.

Nurhayati, N., Saputri, D. F., \& Assegaf, S. L. H. (2019). Pengembangan instrumen tes keterampilan proses sains pada materi Fisika untuk siswa sekolah menengah pertama. Edukasi: Jurnal Pendidikan, 17(2), 145-158. http://dx.doi.org/10.31571/edukasi.v17i2.1250.

Papa-Gusho, L., \& Biçaku-Çekrezi, R. (2015). Factors that affect effective planning skills of the teacher in the classrooms. Academic Journal of Interdisciplinary Studies, 4(3), 560-564. https://doi.org/10.5901/ajis.2015. $\mathrm{v} 4 \mathrm{n} 3 \mathrm{~s} 1 \mathrm{p} 560$.

Rahayu, S., \& Mertha, I. (2017). Pengembangan bahan ajar Micro Teaching untuk melatih kompetensi pedagogik calon guru. Jurnal Pendidikan Fisika dan Teknologi, 3(2), 232-238. https://doi.org/10.29303/jpft.v3i2.418. 
Edukasi: Jurnal Pendidikan, Volume 19 Nomor 1 Tahun 2021

Pengembangan Instrumen Microteaching.......

Rahmat Rasmawan

Halaman 31-45

Setiawan, I., \& Mulyati, S. (2019). Efektivitas mata kuliah Pembelajaran Mikro (Microteaching) terhadap keterampilan dasar mengajar dan kesiapan mengajar (Survey pada mahasiswa FKIP semester genap T.A 2017/2018). Equilibrium: Jurnal Penelitian Pendidikan dan Ekonomi, 15(02), 51-60. https://doi.org/10.25134/equi.v15i02.1619.

Shekhar, P., Demonbrun, M., Borrego, M., Finelli, C., Prince, M., Henderson, C., \& Waters, C. (2015). Development of an observation protocol to study undergraduate engineering student resistance to active learning. International Journal of Engineering Education, 31(2), 597-609.

Subagia, I. W., \& Wiratma, I. G. L. (2016). Profil penilaian hasil belajar siswa berdasarkan kurikulum 2013. JPI (Jurnal Pendidikan Indonesia), 5(1), 3955. https://doi.org/10.23887/jpi-undiksha.v5i1.8293.

Taherdoost, H. (2016). Validity and reliability of the research instrument: How to test the validation of a questionnaire/survey in a research. International Journal of Academic Research in Management (IJARM), 5(3), 28-36. https://doi.org/10.2139/ssrn.3205040.

Tazali, I. (2017). Implementasi program Micro Teaching bagi guru Bahasa Arab di Pesantren Ar-Raudhatul Hasanah Medan. EDU-RILIGIA: Jurnal Ilmu Pendidikan Islam dan Keagamaan, 1(2), 222-234. https://doi.org/ 10.47006/er.v1i2.899.

Yane, S., \& Rustanto, H. (2020). Pengembangan instrumen identifikasi bakat dan program pelatihan fisik bagi calon atlet O2SN. Jurnal Pendidikan Olah Raga, 9(2), 202-211. http://dx.doi.org/10.31571/jpo.v9i2.1458.

Yunus, M., Andari, K. D. W., \& Islam, M. A. (2017). The Principal's competences in implementing cultural and environmental management of the school in SDN 033 Tarakan. JPI (Jurnal Pendidikan Indonesia), 6(2), 263-273. https://doi.org/10.23887/jpi-undiksha.v6i2.11982.

Yusoff, M. S. B. (2019). ABC of content validation and content validity index calculation. Education in Medicine Journal, 11(2), 49-54. https://doi.org/ 10.21315/EIMJ2019.11.2.6. 